\title{
バガス纎維複合化ポリ乳酸の機械的特性と熱特性
}

\author{
阪 本 浩 規 ${ }^{* 1}$.今 村信 幸*2 西野雄 大*3 \\ 川崎真 — $^{* 4}$. 山田和 志 ${ }^{* 4}$ 西村寛 之 ${ }^{* 4}$
}

\section{Evaluation of Mechanical and Thermal Properties on a Composite Material of Bagasse Fiber and PLA}

\author{
Hiroki, Sakamoto*1/Nobuyuki, Imamura ${ }^{* 2} /$ Takahiro, Nishino ${ }^{* 3}$ \\ Shinichi, Kawasaki*4/Yamada, Kazushi*4/Hiroyuki, Nishimura*4
}

In this study, the mechanical and thermal properties of composite materials of bagasse fiber and bio-based polymer of poly (lactic acid) (PLA) were investigated. PLA and bagasse fiber, which is sugar cane residue after squeezing, were compounded into a composite resin and injection-molded to a specimen. The tensile test and the Izod impact test of a composite material of bagasse fiber and PLA were conducted. The tensile strength and the tensile modulus increased with increasing the content of bagasse fiber although the elongation at break slightly decreased. The Izod impact strength of bagasse fiber and PLA with plasticizer after the thermal treatment greatly increased. Micrograph observation showed the bagasse fiber which has a honeycomb structure in the cross section was compressed in the injection molding. The compressed bagasse fiber contributed to increase the tensile strength. It was also found that the tensile strength and the Izod impact strength of a composite material of bagasse fiber and PLA with the surface treatment increased for both before and after the thermal treatment at 70 degrees C. The PLA containing $20 \mathrm{wt} \%$ of bagasse fiber had high heat resistance, but the PLA compound containing $20 \mathrm{wt} \%$ of bagasse fiber and $10 \mathrm{wt} \%$ of plasticizer had the higher heat resistance. The XRD, DSC, FT-IR analysis clarified the mechanism and roles of bagasse fiber and plasticizer in the crystallization process of PLA. It was found that the crystallization was accelerated due to lignin leached from bagasse fiber.

Key words : Poly lactic acid (PLA), Bagasse fiber, Mechanical properties, crystallization

${ }^{* 1}$ 大阪ガス侏) エネルギー技術研究所

Energy Research Laboratory, Osaka Gas Co., Ltd.

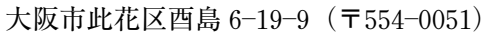

6-19-9, Torishima, Konohana-ku, Osaka 554-0051, Japan

hsakamot@osakagas.co.jp

*2 大阪樹脂工業(侏)

Osaka Resin Industry Co., Ltd.

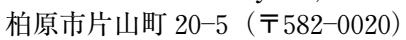

20-5, Katayama-cho, Kashiwara, Osaka 582-0020, Japan

*3 大阪ガスケミカル(株)

Osaka Gas Chemicals, Ltd.

大阪市西区千代崎三丁目南 2-37（㣙50-0023）

2-37, Chiyozaki 3-chome-minami, Nishi-ku, Osaka 550-0023, Japan

*4 京都工芸瀻維大学

Kyoto Institute of Technology

京都市左京区松ヶ崎（７606-8585）

Matsugasaki, Sakyo-ku, Kyoto 606-8585, Japan

2014. 12.24 受理

\section{1. 緒}

言

温室効果ガス排出削減による「低炭素社会」や，環境に 調和した「資源循環型社会」の実現に向けた取り組みが強 く求められており，これらの社会を実現するためにバイオ マスプラスチックの物性向上による利用の拡大が大きな課 題となっている．また，サトウキビの世界的な生産は 2002 年で 12.9 億トンと言われており, サトウキビの搾りかす であるバガスの排出は 1 億トン以上（乾燥重量換算）と推 定される。この大量に排出されるバガスをどのように処理 し，有効利用するかはそれぞれ国にとって大きな社会問題 になっている．沖縄県ではサトウキビが基幹作物であり， 約 40 万トンのバガスが排出されている.ところが，バガ 又繊維は, 製糖工場におけるボイラー, 自家発電の燃料と しての利用が主であり, 付加価值の高い利用方法はあまり なく, 余剩分は産業廃裹物として処理されている. そこで, バガス瀻維とポリエチレンの BMC (Bulk Molding Compound）複合材料の作製が試みられており，直鎖状低密度 
ポリエチレンに短繊維のガラス繊維と短繊維のバガス繊維 を組み合わせた射出成形品では, 成形体のバガス繊維含有 量が増加するにつれ, 引張強度の向上と収縮率の改善に効 果があることが認められている ${ }^{1)}$ ままた，その他にもバガ ス繊維を用いた複合材料の作製がいくつか試みられており， 曲げ弾性率の向上が図れることが報告されている2) 4).

一方，ポリ乳酸（PLA）は，植物由来樹脂であり，製 造時, 燃焼時の二酸化炭素発生量も少ないことから, 包装 容器用途を中心に利用されつつあり，材料の機械的物性の 改良と共に成形性やフィルムのヒートシール等の 2 次加工 性に関しても研究が進められている ${ }^{5)}$. 一方で, 耐熱性 や衝撃強度等はまだ十分であるとは言えず，未だ爆発的な 普及には至っていない. PLAの環境特性を損なわず耐熱 性や強度を実用レベルまで改良する手段として, ケナフ繊 維などの植物繊維を添加する方法があり，この方法により 高耐熱・高強度な PLA 複合材料が開発され, 電子機器の 外装にも実用化が図られている ${ }^{7) ~ 9)}$. 家電機器やガス機器 等, より幅広い用途への植物由来樹脂の適用を行うために は, より高い機械的強度, 耐熱性, 成形性, 耐加水分解性 等の特性，および低コスト化が必要とされる。

筆者らはバガス繊維に関して, 軽量化が期待できる多孔 構造 (ハニカム構造)，および大規模な収穫 - 集荷 ・分別 · 洗浄による生産の効率性とバイオマス材料としての均一性 があることに着目し, 将来的に他のバイオマス繊維と比較 して物性面, コスト面で優位性が得られると考え, PLA とバガス繊維の複合樹脂材料を試作した. その結果, バガ スの添加量に応じて曲げ弾性率が向上すると同時に, 食品 残渣のバイオガス化システムにおいて, PLA とバガス繊 維の複合樹脂材料が可溶化し，バイオガスに転換すること を見出し, バイオマスエネルギー創出の観点からも有益な 材料であることが分かった ${ }^{10)}$. 一方で，単純にバガスを添 加するだけでは物性は不十分であり, バガス䋊維複合化 PLAの機械的強度, 耐熱性の向上が求められている. 例 えば, Escamilla らの研究では, PLA とバガスの混練を行 い，機械強度の測定と DSC による結晶化挙動を調べてい るが, バガスの添加量の増大により曲げ弾性率, 曲げ強度 の上昇がほとんど見られず，結晶化度は上昇するものの結
晶化温度は数 ${ }^{\circ} \mathrm{C}$ 程度の変化しか見られない ${ }^{11)}$.

本研究では，バガス繊維と PLA との複合樹脂材料に関 して添加剂や表面処理を加え, 耐熱性と機械特性を評価し た。また，その配合・処理と特性の相関を明らかにし，バ ガス繊維複合化 PLA の物性向上の要因の解明を試みた.

\section{2. 試験材料と実験方法}

\section{1 試験材料}

ポリ乳酸（PLA）はメルトフローレートが 5 (g/10 min.) $\left(2.15 \mathrm{~kg}, 190^{\circ} \mathrm{C}\right), \mathrm{L}$ 体の含有率が $2 \%$ の REVODE 110

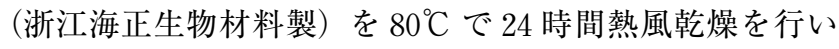
使用した. バガス繊維は製糖工場から排出されたもの

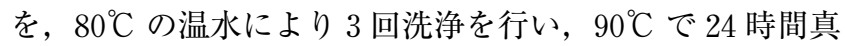
空乾燥した, 繊維長平均が約 $10 \mathrm{~mm}$ のものを使用した. また, PLA に対して耐衝撃性を付与する狙いと PLAの末 端カルボキシル基とバガス繊維に含まれるフェノール性 $\mathrm{OH}$ 基を結合する狙いを満たす添加郕として，柔軟なアル キル構造を有し, かつ複数の反応性官能基を有する脂肪族 エポキシ樹脂（1, 6-ヘキサンジオールジグリシジルエーテ ル）を用いた。

\section{2 コンパウンド樹脂の配合}

表 1 に示す配合で PLA へのエポキシ樹脂への添加の有 無，バガス繊維への表面処理の有無とその条件，バガス繊 維の比率を変えて混練を行った.

サンプル 2 については, PLA とエポキシ樹脂を $7: 1$ で 混合し, 2 軸押出機 (日本製鋼所製 LABOTEX 30 HSS-32. 5 $\mathrm{PW}-2 \mathrm{~V})$ を用い，バレル温度 $180^{\circ} \mathrm{C}$ にて溶融混練するこ とにより作製すると同時に，サンプル 4-1〜4-3 およびサ ンプル 6 の原料とした. サンプル 3-1〜3-3 については, PLA とバガス繊維を $8: 2$ の比率で $190^{\circ} \mathrm{C}$ で混練すること により作製した. サンプル 4-1〜4-3 は，サンプル 2 と， バガス繊維を $8: 2$ の比率で $190^{\circ} \mathrm{C}$ で混練することにより 作製し, 全体に対するバガス繊維の比率をサンプル 3-1 3-3 と同じ $20 \mathrm{wt} \%$ で統一した.

サンプル 3-2，3-3，および 4-2，4-3 については，1 $\mathrm{wt} \%$ もくは $5 \mathrm{wt} \%$ 濃度の上記エポキシ樹脂のメ夕ノー ル溶液にバガス繊維を浸漬し，表面処理を行った後に真空

Table 1 Compound ratios of PLA/Bagasse fiber/additive

\begin{tabular}{ccccl}
\hline \hline No. & $\begin{array}{l}\text { PLA } \\
(\text { REVODE 110) } \\
(\%)\end{array}$ & $\begin{array}{l}\text { Bagasse } \\
\text { fiber } \\
(\%)\end{array}$ & $\begin{array}{l}\text { Epoxy } \\
(\%)\end{array}$ & Remark \\
\hline 1 & 100 & & & \\
\hline 2 & 87.5 & & 12.5 & \\
\hline $3-1$ & 80 & 20 & & \\
\hline $3-2$ & 80 & $20 \%$ & & $※ 1 \%$ epoxy-treated bagasse \\
\hline $3-3$ & 80 & $20 \%$ & & $※ 5 \%$ epoxy-treated bagasse \\
\hline $4-1$ & 70 & 20 & 10 & \\
\hline $4-2$ & 70 & $20 ※$ & 10 & $※ 1 \%$ epoxy-treated bagasse \\
\hline $4-3$ & 70 & $20 ※$ & 10 & $※ 5 \%$ epoxy-treated bagasse \\
\hline $4-4$ & 70 & 20 & 10 & $*$ one pass extruding \\
\hline 5 & 70 & 30 & & \\
\hline 6 & 61.25 & 30 & 8.75 & \\
\hline
\end{tabular}


乾燥したものを用いた。 また，サンプル 4-4 はサンプル 4 -1 と同等の配合で PLA，バガス繊維，エポキシ樹脂を 2 段階ではなく 1 段階で混練し, PLAの変性, バガス繊維 の表面処理を一括で行ったものである. サンプル 5 はサン プル 3-1 のバガス繊維の比率を $30 \mathrm{wt} \%$ に高めたものであ り, サンプル 6 はサンプル 4-1 と比較して PLA/エポキシ 樹脂比は変えずにバガス繊維の比率を $30 \mathrm{wt} \%$ に高めたも のである.

\section{3 複合樹脂の成形}

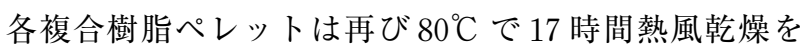
行った後，射出成形機（Po Yuen 製 UM 50）を用い，表 2 に示す条件で成形を行い, JIS K 7161 に規定されている 長さ $175 \mathrm{~mm} \times$ 平行部幅 $10 \mathrm{~mm} \times$ 平行部長さ $50 \mathrm{~mm} \times$ 厚 さ $3 \mathrm{~mm}$ のダンベル状の試験片を得た。なお, サンプル 2 のみ柔軟で取り出し時に変形しやすいため金型温度を $10^{\circ} \mathrm{C}$ とした。アイゾット衝撃試験片は上記ダンベル状試 験片と同じ温度条件で, 長さ $80 \mathrm{~mm} \times$ 幅 $3 \mathrm{~mm} \times$ 厚さ 10 mmのものを作製した。

\section{4 自重によるたわみ量の測定}

JIS K 7195 に規定されているヒートサグ試験を参考にし て，各バガス繊維複合樹脂のダンベル状の試験片を，端部 から $30 \mathrm{~mm}$ の地点から片持ち状態にして温度 $80^{\circ} \mathrm{C}$ の恒温 槽に 3 時間保持し，熱変形量を測定し，相対的な耐熱性を 調べた。

\section{5 引張試験}

万能試験機（Instron 製 Type 55 R 4206）を用い，JIS $\mathrm{K} 7161$ に準じてダンベル状の試験片の引張試験を行った 試験条件としては室温 $23^{\circ} \mathrm{C}$, 引張速度は $5 \mathrm{~mm} / \mathrm{min}$ で行 い, 引張弾性率と破断強度を求めた. 引張弾性率は伸び $0.05 \%(0.025 \mathrm{~mm})$ と $0.25 \%(0.125 \mathrm{~mm})$ のひずみに 対応する応力から求めた.

\section{6 アイゾット衝撃試験}

アイゾット衝撃試験機 (東洋精機製作所製 Type DB-IB) を用い，JIS K 7110 に準じて衝撃試験を行った. 試験条件 は室温 $23^{\circ} \mathrm{C}, \mathrm{n}=5$ で行い, 各バガス繊維複合樹脂のアイ ゾット衝撃值の平均值を求めた。

衝撃強度は射出成形製品の実使用上最も重要な物性の一 つであるが，特にPLAのような結晶性樹脂の場合，成形 条件に左右されることが多い.また，本研究の配合におい てはバガス中の成分による結晶化促進, エポキシ系添加剂 による化学反応等による物性向上が期待できたことから,

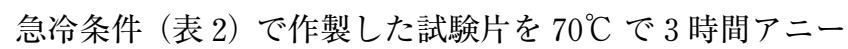
ルし, 安定な状態にしたサンプルを用いて再度衝撃強度を 測定し, 各配合のポテンシャルを推察した. 加えて, アニー ル前後の物性の変化の配合（バガス/添加剤の有無）によ る違いを見ることにより, 各成分の物性に及ぼす効果を推 定することができる。

Table 2 Temperature of injection molding

\begin{tabular}{lcccccc}
\hline \hline & $\begin{array}{c}\text { Zone } 1 \\
\left({ }^{\circ} \mathrm{C}\right)\end{array}$ & $\begin{array}{c}\text { Zone } 2 \\
\left({ }^{\circ} \mathrm{C}\right)\end{array}$ & $\begin{array}{c}\text { Zone } 3 \\
\left({ }^{\circ} \mathrm{C}\right)\end{array}$ & $\begin{array}{c}\text { Zone } 4 \\
\left({ }^{\circ} \mathrm{C}\right)\end{array}$ & $\begin{array}{c}\text { Nozzle } \\
\left({ }^{\circ} \mathrm{C}\right)\end{array}$ & $\begin{array}{c}\text { Mold } \\
\left({ }^{\circ} \mathrm{C}\right)\end{array}$ \\
\hline Sample 2 & 150 & 180 & 185 & 190 & 200 & 10 \\
\hline Others & 150 & 180 & 185 & 190 & 200 & 30 \\
\hline
\end{tabular}

\subsection{SEM 観察}

各バガス繊維複合樹脂の引張試験およびアイゾット衝撃 試験後の破面を，走査型電子顕微鏡（日本電子（株）製, JSM－6010 LA）を用いて観察した. バガス繊維の形状や PLA とバガス繊維の混合状態および界面の密着性を定性 的に確認することができる.

\subsection{DSC 測定}

後述の耐熱性試験結果，アニール前後のアイゾット衝撃 強度試験結果（3.1，3.2）において, バガス繊維及び添加 したエポキシ樹脂の PLAの結晶化への寄与が推定できた ことから, 示差走査熱量計 (TA Instruments 製 DSC Q 2000）を用いて結晶化挙動の分析を行った.

まず, PLA 単体で予備試験を行った結果, 1 stRUN の 降温速度 $50^{\circ} \mathrm{C} / \mathrm{min}$ 以上で非晶化した。また， 2 ndRUN の昇温速度については, 昇温速度 $5{ }^{\circ} \mathrm{C}$ 以上では結晶化が 昇温に追い付かず，実際の結晶化よりも高い温度で発熱 ピークが見られる，もしくは発熱ピークが観察できない現 象が見られ，2〜 $3{ }^{\circ} \mathrm{C} / \mathrm{min}$ で結晶化挙動が十分に観察でき た. 一方, 昇温速度 $1{ }^{\circ} \mathrm{C}$ では結晶化ピークがブロードに なり結晶化の立ち上がりと終了が不明確になった。

これらの結果から, 昇温速度 $3^{\circ} \mathrm{C} / \mathrm{min}$ で $210^{\circ} \mathrm{C}$ まで昇 温したサンプルを, PLA 単体であれば結晶化しない降温 速度 $50^{\circ} \mathrm{C} / \mathrm{min}$ で冷却し, 再度 $3^{\circ} \mathrm{C} / \mathrm{min}$ で昇温する条件 で, 2 ndRUN における結晶化ピーク温度と面積の測定を 行った.

\section{$2.9 X$ 線回折 (XRD)}

DSC 測定によって得られた各成分の PLAの結晶化に対 する効果を確認するため, PLA 単体 (サンプル 1), PLA +エポキシ樹脂 (サンプル 2), PLA+バガス繊維（サン プル 3-1), PLA + バガス繊維＋エポキシ樹脂（サンプル 4-1）のダンベル試験片の X 線回折を測定することにより, PLA 部分の結晶性を観察した.

測定は，リガク社製 RINT 2400 を用い，管電圧 $50 \mathrm{kV}$, 管電流 $150 \mathrm{~mA}$, 測定角度範囲 $2 \theta=5^{\circ} \sim 85^{\circ}$, ステップ幅 $0.01^{\circ}$, 走査速度 $5^{\circ} / \mathrm{min}$ の条件で行った.

\subsection{FT-IR マッピング解析}

バガス繊維中の成分の PLAへの影響を調べる第一歩と してバガスに含まれるリグニンの PLAへの拡散状態を調 ベた.

PLA，および今回用いたエポキシ樹脂ともにベンゼン 環を有しないため, 複合樹脂中のベンゼン環の濃度がリグ ニンの濃度を表すと考えられる。 そこで, FT-IR (Thermo Fisher Scientific 社製 Nicolet iN 10 MX) を用い，10 $\mu \mathrm{m}$ $\times 10 \mu \mathrm{m}$ の微細な面積ごとの $1600 \mathrm{~cm}^{-1}$ (ベンゼン環の C $=\mathrm{C}$ 伸縮振動）のピーク強度を測定し，マッピングを行っ た.この方法により，複合樹脂中のリグニン成分の分布を 半定量的に求めた.

\section{3. 実験結果および考察}

\section{1 耐熱性の評価}

まず，バガスを添加することによる耐熱性の向上効果を 評価した. ダンベル試験片の $80^{\circ} \mathrm{C} 3 \mathrm{~h}$ 保持後のたわみ量の 結果を図 1 に示す。

PLA にエポキシ樹脂のみを加えたサンプル 2 はたわみ 


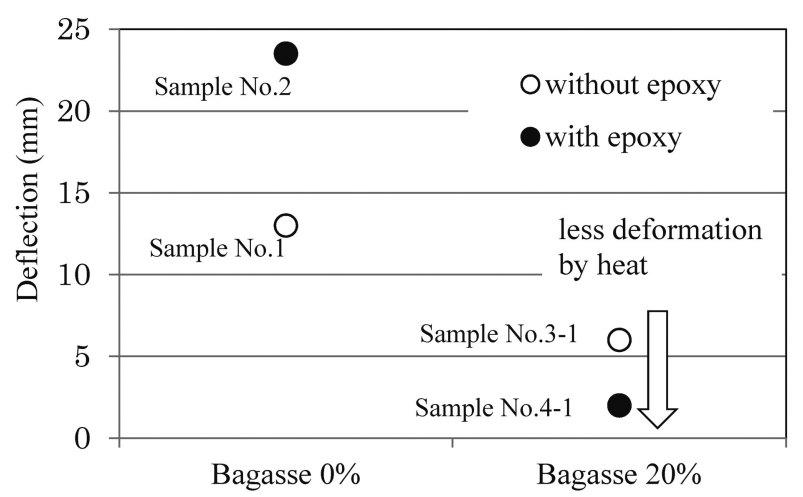

Fig. 1 Results of heat resistance test

量が増大していたが，バガス繊維を添加したサンプル 3-1 については，たわみ量が $13 \mathrm{~mm}$ から $6 \mathrm{~mm}$ と $1 / 2$ 以下と なった. PLA にエポキシ樹脂を加え, さらにバガス繊維 を添加したサンプル 4-1についてはベース樹脂が柔軟に なっているにも関わらず，たわみ量は $6 \mathrm{~mm}$ から $2 \mathrm{~mm}$ と $1 / 3$ に低減した。

つまり, PLA へのエポキシ樹脂添加により，バガス繊 維による物理的な補強効果による耐熱性向上効果とは別の 効果が発現し，耐熱性がさらに向上していることがわかっ た。

\section{2 機械的強度}

表 1 に示す配合の引張試験後の引張弾性率, 引張強度を 図 2 に示す.

引張弾性率に関しては, PLA に予めエポキシを添加し た系（サンプル 2, 4-1〜4-3,6）は，エポキシ非添加系（サ ンプル 1,3-1～3-3,5）と比較してベース樹脂が柔軟となっ た分低い值となった。しかし，同じ系同士で比較するとい ずれの系も, バガス繊維の添加量を増やすほど引張弾性率 が増大していることがわかった.

また， $1 \mathrm{wt} \%$ のポキシ樹脂溶液でバガスの表面処理を 行ったサンプル 3-2，4-2 は，表面処理を行わなかったサ ンプル 3-1，4-1 に対してそれぞれ引張弾性率が増加した. 一方， $5 \mathrm{wt} \%$ エポキシ樹脂溶液で表面処理を行ったサンプ ル 3-3，4-3については， $1 \mathrm{wt} \%$ 処理したものと比較し て引張弾性率は減少しており，過剩のエポキシ樹脂により 可塑効果が生じていることが推測できる.

引張強度に関しては, バガス繊維の添加により低下して いた. サンプル 3-1 の引張試験後の試験片の断面の SEM 観察結果を図 3 に示す. 引張方向に配向した数 $100 \mu \mathrm{m}$ ス ケールのバガス繊維が樹脂から脱落した形跡が見られたこ とから, バガス繊維添加時は PLA 単体と比較して, PLA 一バガス䋊維間の界面における破断が強度低下の要因に なっていると考えられる，一方で，バガスの表面処理によ り引張強度が向上し, 表面処理に用いるエポキシ樹脂が高 濃度であるほど向上幅が大きい傾向がみられたことから， エポキシ樹脂によりバガス繊維と PLAの界面の接着性が 強化されたためであると考えられる。

アイゾット衝撃強度試験の結果を図 4 に示す。エポキシ 樹脂のみを添加したサンプル 2 がサンプル 1 の PLA 単体 と比較して衝撃強度が向上していたが, サンプル 3-1〜 6 のバガス繊維を添加した系ではサンプル 1 および 2 のバガ

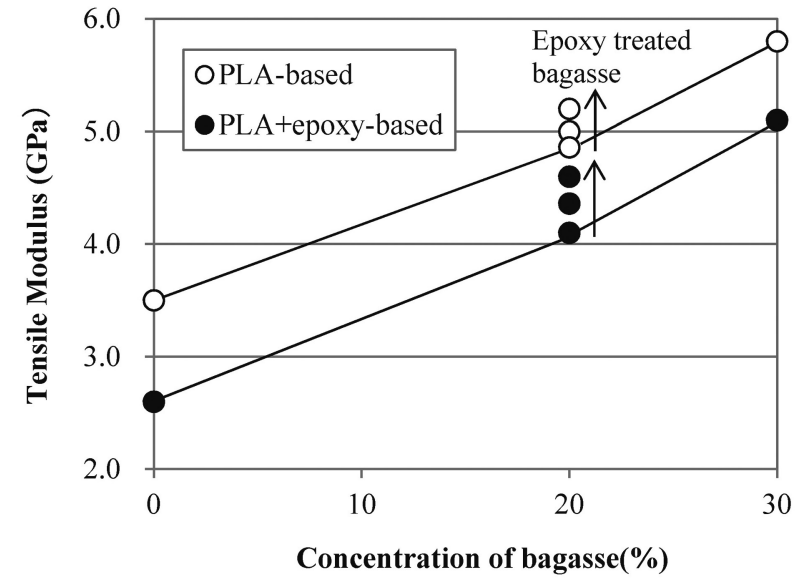

(a) Tensile modulus

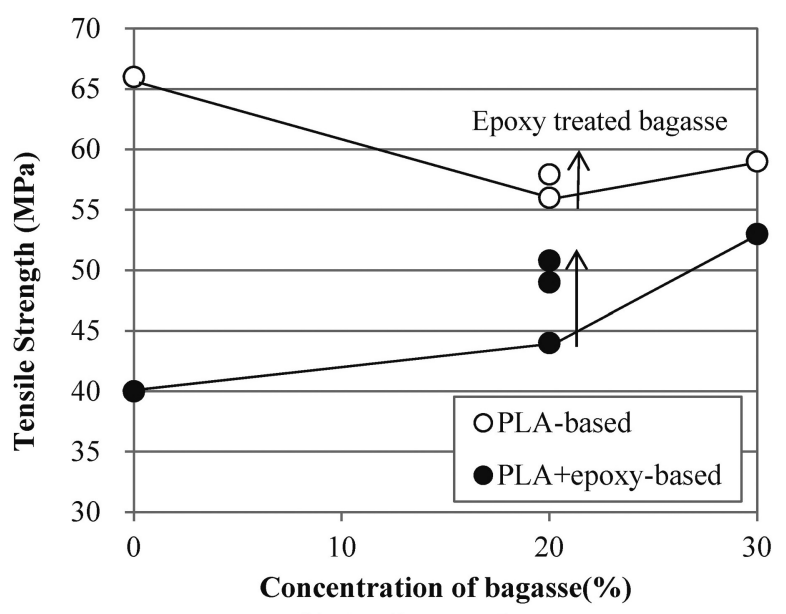

(b) Tensile strength

Fig. 2 Results of tensile test (a) Tensile modulus (b) Tensile strength

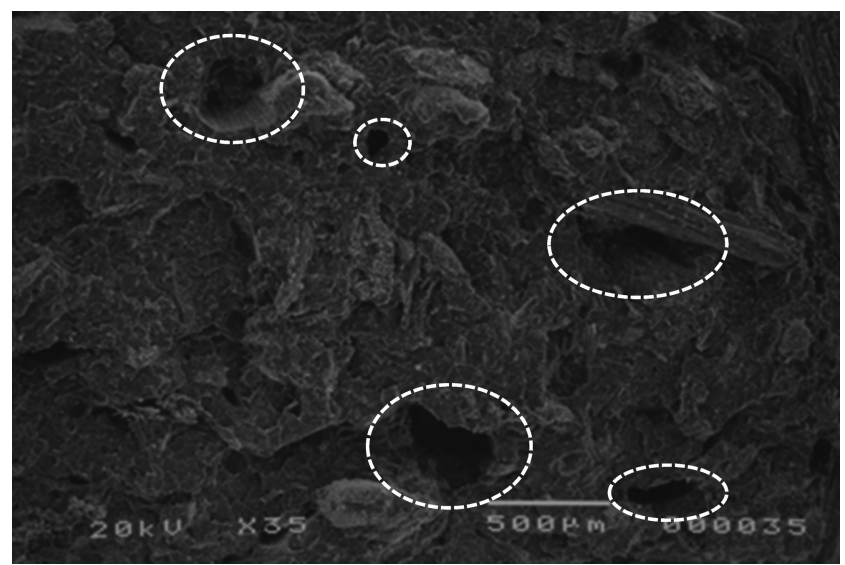

Fig. 3 SEM image of broken surface after tensile test

ス繊維を添加しない系と比較してアイゾット衝撃強度は低 下した。

しかし，3.1の結果から, PLA 単体に対して耐熱性が 向上しているバガス繊維を添加している系のみで, サンプ ル 3-1（PLA+バガス 20\%）を基準として比較を行った ところ, PLAへのエポキシ樹脂の添加, 及びバガス繊維 の表面処理のいずれの処理についても衝撃強度向上効果が 見られた. 特にPLAへのエポキシ樹脂の添加を行ってい ない系において，表面処理を行ったサンプル 3-2, 3-3 


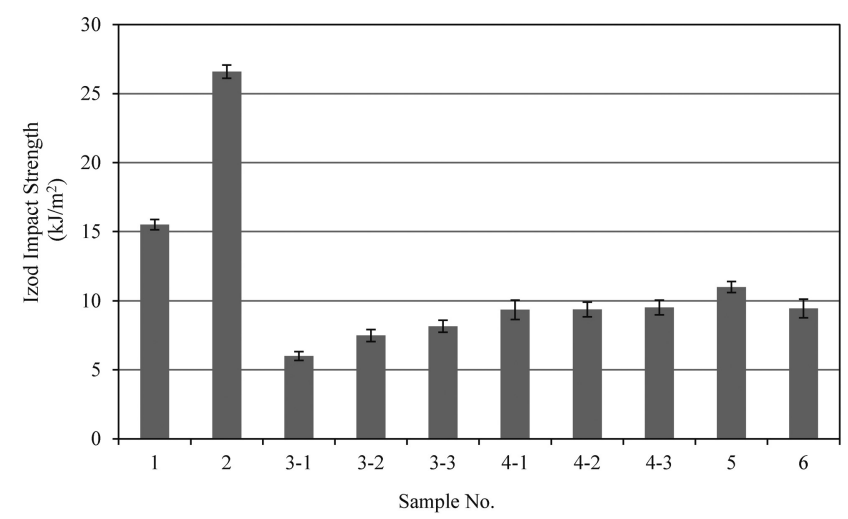

Fig. 4 Izod impact strength of PLA/bagasse compounds

がサンプル 3-1に対して衝撃強度向上幅が大きかったこと から，バガス繊維と PLA の界面の接着性が衝撃強度を左 右する大きな要因であることが推測できた.

$70^{\circ} \mathrm{C} 3 \mathrm{~h}$ のアニール前後のアイゾット衝撃強度の変化を 図 5 に示す。その結果，サンプル 5 を除いてアイゾット衝 撃強度はいずれも向上し，かつ PLAにエポキシ樹脂未添 加であるサンプル 1，3-1，5に対して，PLA に予めエポ キシ樹脂を添加したサンプル 2，4-1，6の方がアニールに よるアイゾット衝撃強度向上の幅が大きかった。このア ニール前後の衝撃強度の比較結果と耐熱性の評価結果を併 せて考えると, エポキシ樹脂が PLA-バガス瀻維界面の接 着性を高める効果を有することに加えて, PLA に添加さ れた場合は樹脂全体の結晶化を促進し, 耐熱性及び衝撃強 度向上を促進した可能性が示された。

\subsection{DSC 測定による結晶化温度と結晶化速度の比較}

3.2 の考察を検証するために，それぞれバガス瀻維の有 無とエポキシ樹脂添加の有無が異なるサンプル $1,2,3-$ 1，4-1についてDSC の測定を行い，2 ndRUNにおける 結晶化ピーク温度と結晶化時の発熱ピーク面積を測定し, 発熱ピーク面積についてはPLAの重量当たりに変換した。 DSC 測定結果を図 6, 図 7 に示す。

まず，結晶化温度についてはベースのPLAにエポキシ 樹脂を添加しているサンプル 2 と 4-1 が，エポキシ樹脂未 添加のサンプル 1 と 3-1 と比較して低かった. PLAの可

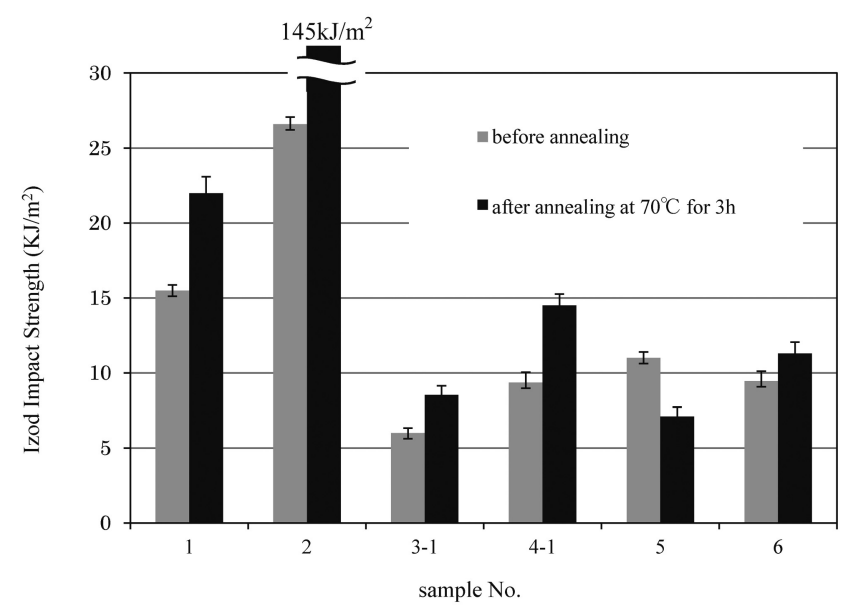

Fig. 5 Improvement of Izod impact strength after annealing

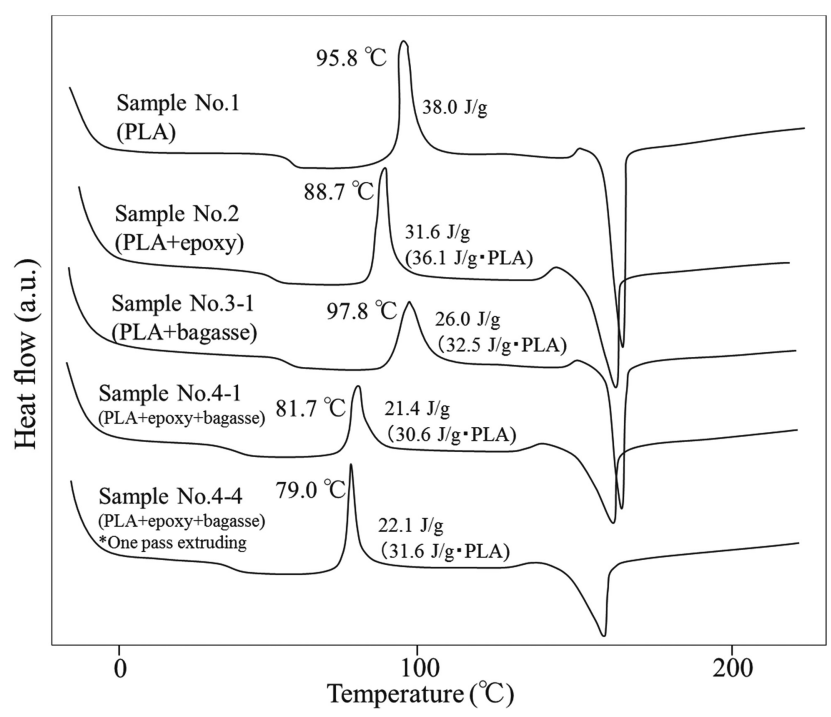

Fig. 6 Thermal property of compounds with $\operatorname{DSC}(2$ nd RUN)

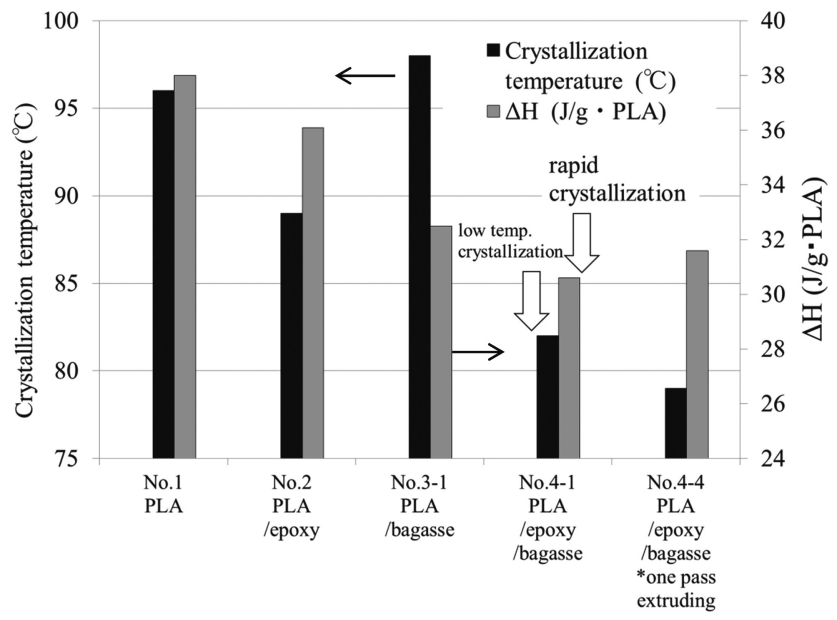

Fig. 7 Crystallization property of compounds with DSC (2 nd RUN)

塑化効果のあるエポキシ樹脂の添加により PLA の分子鎖 が動きやすくなり，低い温度で結晶化が開始したと推定で きる．逆にバガス繊維のみを添加しているサンプル 3-1に ついては, 結晶化温度の低減効果はなかった。

一方, 発熱ピーク面積に関しては, バガス繊維を添加し たサンプル 3-1，4-1，4-4 の方がバガス緎維の未添加 のサンプル 1，2に対して小さくなっていた。これは, PLA 単体で結晶化が発生しない $1 \mathrm{stRUN}$ の降温時 $\left(50^{\circ} \mathrm{C} / \mathrm{min}\right)$ においても，PLAにバガス纎維を添加した系においては 結晶化が発生し，その結果 2 ndRUN における結晶化が少 なかったことを示しており，実成形時にも金型内での結晶 化が促進されることが期待できる.

上記の結果から，エポキシ樹脂の添加により結晶化温度 が下がり，バガス繊維の添加により結晶化速度が上がると いう，それぞれ異なる添加効果があることがわかった．ま た，サンプル 4-1の結果に扔いては，エポキシ樹脂とバガ ス瀻維をそれぞれ片方のみ添加した場合よりさらに結晶化 温度の低下効果と降温時の結晶化効果が増大していること から，両者を添加することにより結晶化促進の相乗効果が 
みられることがわかった。 なお，バガス繊維とエポキシ樹 脂と PLA を同時に混練したサンプル 4-4についても，同 様の相乗効果が見られ, かつ結晶化温度についてはさらに $3{ }^{\circ} \mathrm{C}$ 低かった。つまり, 必ずしも PLA の変性とバガス繊 維の表面処理を分けて行った後に混練する必要が無いこと がわかった。

\section{$3.4 X$ 線回折（XRD）による結晶構造の解析}

サンプル 2，3-1，4-1 とサンプル 1 のポリ乳酸単体を XRD で比較した結果を図 8 に示す。

サンプル 2 のエポキシ樹脂のみ添加した系では, $2 \theta=$ $16.5^{\circ}$ 付近 (200/110) 面, $19.1^{\circ}$ 付近 (203) 面の $\alpha$ 型結 晶由来の回折ピークがわずかに増大している以外は結晶性 に殆ど差異がみられなかった。サンプル 3-1 のバガス繊維 のみ添加した系では, $16.5^{\circ}$ 付近のピーク増大と, 新たに $22^{\circ}$ 付近の（210）面を表すと思われるピークが観察され, 結晶性の増大が見られた。 バガス繊維とエポキシ樹脂の両 方を添加した系では，結晶性の大幅な向上が見られ，上記 の 3 カ所のピークが非常に鋭い形で観察された。この結果 により，バガス繊維の成分が結晶化を速め，かつバガス繊 維とエポキシ樹脂の相乗効果が得られるという 3.3 の熱分 析結果を裏付ける結果が得られた。

\subsection{FT-IR マッピング解析によるリグニンの濃度分布}

サンプル 4-4の射出試験片中における, リグニンの濃度 を表す $1600 \mathrm{~cm}^{-1}$ のピーク強度の分布を図 6 に示す。点線 は顕微鏡画像で得た同じ視野におけるバガスの分布である. この結果から，バガス繊維近傍の PLA からもリグニンが 検出され，ポリ乳酸中にリグニンが拡散していることが示 されたが，ポリ乳酸の結晶化挙動への影響はさらに詳細な 検証が必要である.

\section{4. 結言}

ポリ乳酸（PLA）にバガス繊維を添加した複合樹脂材 料の溶融混練, 成形を行い, 機械的特性と熱特性測定を行っ た.PLAにバガス繊維を複合することにより，熱変形を 抑制でき，エポキシ樹脂の添加により PLA が柔軟になっ ているにも関わらず耐熱性がさらに向上することが分かっ た.

一方で，バガス繊維の配合により引張弾性率は増加する が，引張強度，アイゾット衝撃強度は低下する傾向を示し た。ここで，PLAへのエポキシ樹脂の添加，もしくはバ ガス繊維表面のエポキシ樹脂による表面処理により，破断 伸びとアイゾット衝撃強度は回復の傾向を示した。

DSCによる熱分析やX 線回折により，バガス繊維が結 晶化速度を増す効果，エポキシ樹脂が結晶化温度を低くす る効果を有し，それらを併用した場合，その 2 つの効果が より促進され, 耐熱性, 衝撃強度がさらに向上することが わかった。 今後，バガス繊維に限らず植物性の成分と，可 塑効果のある添加剤の相乗効果により, 金型温度の低減や 成形サイクルの短縮など実製造上の効果も期待できる.

PLA とバガス繊維のバイオマス同士の複合材料は, PLA にとってはバガス繊維により物性が向上することができ, バガス繊維にとってはPLA 中に固定され二酸化炭素に変 換されるまでのサイクルを長くすることができ, 最終的に は丸ごとバイオガス化してエネルギーとして回収すること

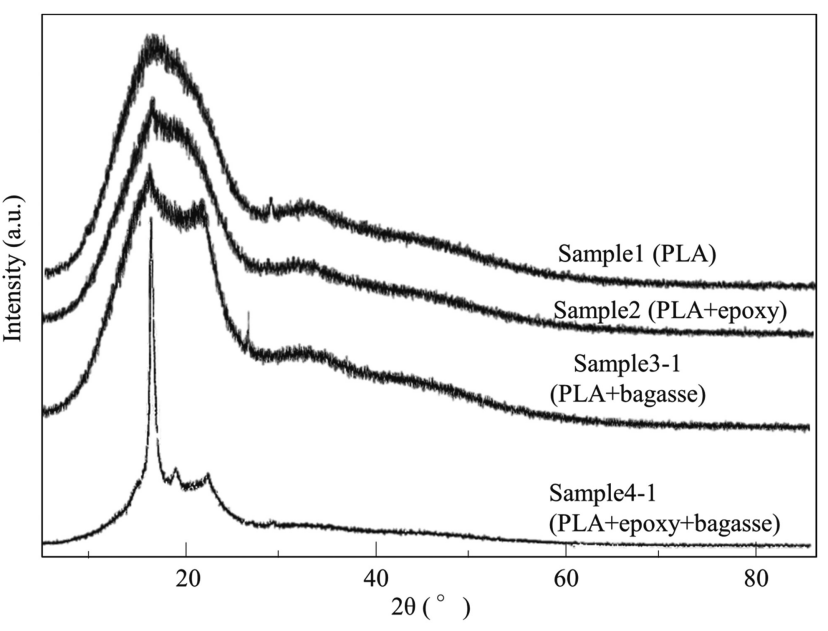

Fig. 8 The difference of crystallinity in XRD spectrum

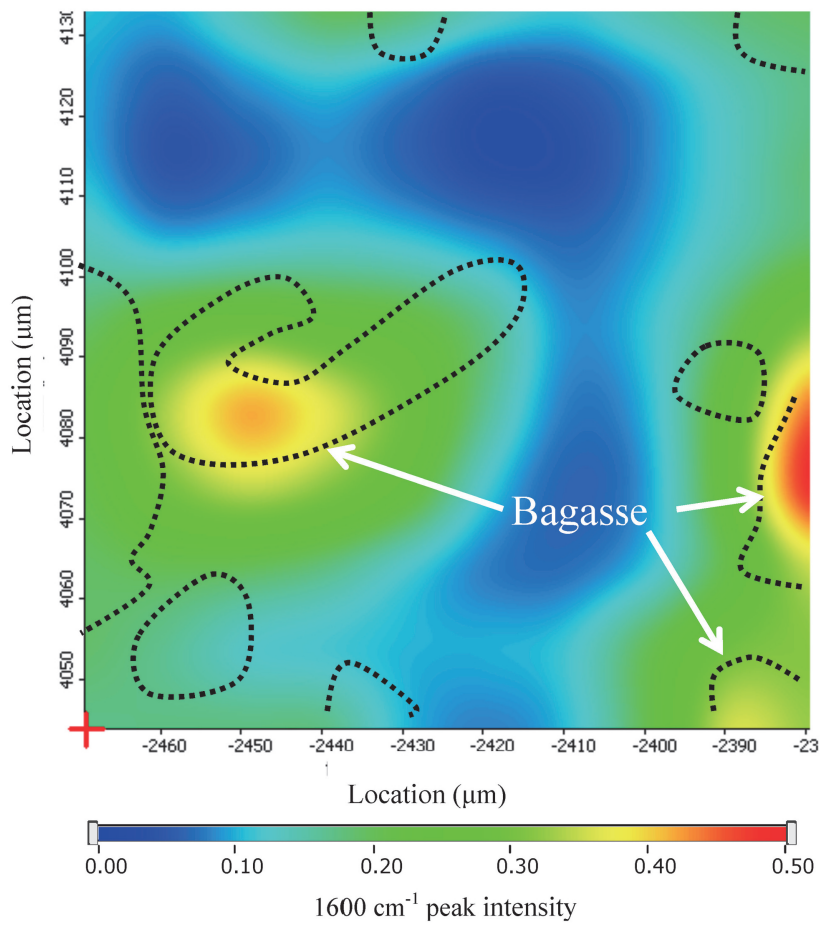

Fig. 9 Lignin concentration distribution in PLA $\left(1600 \mathrm{~cm}^{-1}\right.$ peak intensity in FT-IR analysis)

も可能となる。本研究の結果は, 上記複合材料だけに留ま らず，幅広いバイオマス樹脂，バイオマス繊維を含む複合 材料の実用化の加速にも寄与する沉用的な知見を含むと考 える。

\section{参 考 文 献}

1 ) 柴田信一, 曹勇, 福本功:日本機械学会論文集, 71 (704), $1400(2005)$

2 ）柴田信一，曹勇，福本功：日本機械学会論文集，71 (707), $2414(2005)$

3 ）柴田信一，曹勇，福本功：日本機械学会論文集，71 (707), 2420(2005)

4 ）福本功, 銘苅春栄：成形加工，10(11)，898（1998）

5 ) 橋本靜生, 橋本由美, 辻井哲也, 森本光彦, S. I. Umaru, 
濱田泰以：成形加工，18(8)，600(2006)

6 ) 坪田潤，川崎真一：日本接着学会，31(2)，41(2011)

7 ) 芹澤慎, 井上和彦, 位地正年：高分子論文集, 62 (4), 177 (2005)

8 ）位地正年：ゴム協会誌，81(5)，181(2008)

9 ）位地正年，井上和彦，芹澤慎，木内幸浩，中村彰信,
柳澤恒徳，山城緑：高分子論文集，68(6)，370(2011)

10) Sakamoto, H., Kawasaki, S., Tsubota, J., Nishino, T., Imamura, N., Nishimura, H. : Polymer Preprints, Japan, 2026 (2012)

11) Canché-Escamilla, G., Duarte Aranda, S. : Sustainable and Integral Exploitation of Agave, 138(2014) 